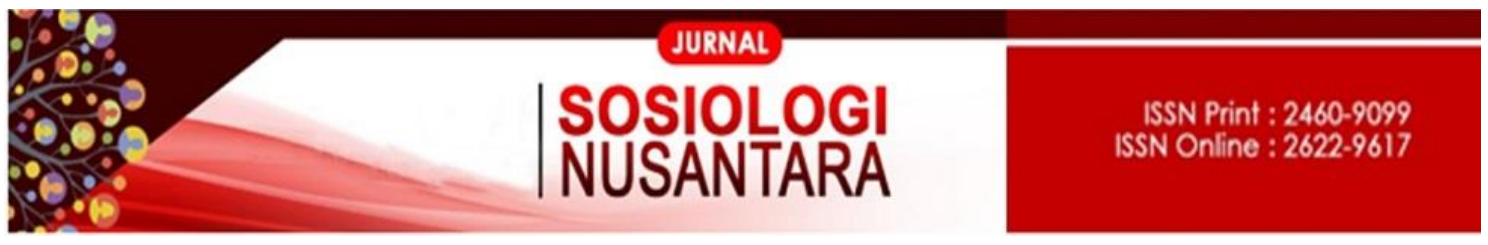

https://ejournal.unib.ac.id/index.php/jsn

DOI ://doi.org/10.33369/jsn.3.2.53-63

\title{
MENENGGAK MINUMAN KERAS DALAM ACARA ENJOY: (Studi Kasus di Desa Sungai Jernih Kecamatan Seberang Musi, Kabupaten Kepahiang)
}

IMPLEMENTING HARD DRINKS IN ENJOY EVENTS: (Case Study in Sungai Jernih Village, Seberang Musi District, Kepahiang District)

\author{
Pernando $^{1}$, Sri Handayani Hanum ${ }^{2}$, Heni Nopianti ${ }^{3}$ \\ Hanum_bkl@yahoo.com \\ 123. Fakultas Ilmu Sosial dan Ilmu Politik, Universitas Bengkulu
}

\begin{abstract}
Abstrak
Penelitian ini dilakukan di Desa Sungai Jernih, Kecamatan Seberang Musi, Kabupaten Kepahiang. Penelitian ini bertujuan untuk menjelaskan mengapa acara enjoy menjadi tradisi baru dalam masyarakat, dimana dalam acara tersebut terdapat kebiasaan masyarakat mengkonsumsi minuman keras pada saat ada hajatan pernikahan. Secara spesifikasi penelitian ini bertujuan untuk mengetahui sejak kapan acara enjoy tersebut menjadi tradisi, dan apa fungsi acara enjoy tersebut diadakan ketika hajatan, serta untuk mengetahui bagaimana peredaran minuman keras ketika acara enjoy. Untuk mencapai tujuan penelitian tersebut, maka metode yang digunakan dalam penelitian ini adalah metode kualitatif dengan analisis deskriptif dengan menggunakan teknik pengumpulan data observasi, wawancara, dan dokumentasi. Penentuan informan dalam penelitian ini dengan menggunakan teknik Snowball Sampling, mulai dari informan kunci yaitu masyarakat yang mengetahui banyak tentang acara enjoy, informan biasa yaitu masyarakat yang terlibat langsung dalam acara enjoy dan informan tambahan. Adapun analisis data yang digunakan adalah dengan menggunakan teknik analisis deskriptif kualitatif berdasarkan hasil data yang diperoleh dari informan. Hasil dari penelitian di lapangan menunjukan bahwa, acara enjoy menjadi tradisi baru dalam masyarakat ketika hajatan sejak tahun 2005, dimana setiap diadakannya hajatan selalu diiringi dengan acara enjoy. Alasan adanya minuman keras pada saat pesta hajatan karena daerah Desa Sungai Jernih wilayah yang marginal. Ada beberapa fungsi acara enjoy diadakan ketika hajatan, yaitu: pertama acara enjoy menjadi hiburan dalam masyarakat, kedua adanya acara enjoy untuk meramaikan hajatan dan ketiga acara enjoy sebagai prestise dalam masyarakat. selain itu, dalam acara enjoy terdapat kebiasaan masyarakat dalam mengkonsusmsi minuman keras, kebiasaan ini muncul di masyarakat dikarenakan peredaran minuman keras di Desa Sungai Jernih bebas di perjual belikan, dan ketika enjoy tidak ada larangan dari masyarakat sekitar dan dari pihak keamanan bahkan dibiarkan untuk mengkonsusmsi minuman keras, sehingga acara enjoy pada saat
\end{abstract}


hajatan pernikahan sama halnya dengan acara konsumsi minuman keras yang dibiarkan oleh masyarakat dan telah menjadi tradisi ketika ada hajatan pernikahan.

Kata Kunci: Tradisi Acara Enjoy, Pesta Minuman Keras

\begin{abstract}
This study aims to describe was conducted in the urban village of Sungai Jernih, SubDistrict of Seberang Musi, Kepahiang. This study aims to explain why the event is enjoy being a new tradition in the community, which in the event there is a habit of society consume liquor a time when there is a celebration of the wedding. In the specification of this study aims to know since when the event enjoy tradition, and what functionality event enjoy the celebration, when held as well as to find out how the liquor circulation when the enjoy event. To achieve the goal of the research, then the method used in this research is qualitative method with descriptive analysis using data collection thechnique of observation, interviews, and documentation. Determination of informants in this study by using the snowball sampling technique, starting from they informant community who know a lot about the event enjoy a regular informant, is the community was directly involved in the event enjoy additional informants.As for the analysis of data used a descriptive qualitative analysis technique based on the data obtained from the informant. The result of the research show that the field, the event is enjoy being a new tradition in a society when a celebration since 2005, where each holding a celebration always accompanied with the event enjoy. Reason of liquor at the time of the party because the area of village of Sungai Jernih region that marginal. There are several function of the event enjoy held a celebration when the first event namely: enjoy entertainment in the community, being both the exsistance of the show to enjoy a celebration, and enliven the event enjoy as prestige in the society. In the addiction in the event there is a habit in society enjoy consuming liquor, costume appears in the community due to the liquor circulation in the urban Village of Sungai Jernih in the selling are traded, and when there was no prohibilitions of enjoy the surrounding communities and authorite event allowed to consume alcoholic beverages, so the show is enjoy $t$ the moment of the wedding celebration as well as liquor consumtion events that were left by the community and has become tradition when there is a celebration of the wedding.
\end{abstract}

Keywords: Enjoy Tradition, Liquor Party

\title{
PENDAHULUAN
}

Konsumsi minuman keras menjadi kegiatan yang sering dilakukan para remaja pada saat ini. hal tersebut biasa dilihat dari meningkatnya konsumsi minuman keras pada kalangan remaja berdasarkan hasil riset yang dilakukan Gerakan Nasional Anti Miras (GeNAM). Jika pada 2007 berdasarkan Riset Kesehatan Dasar Departemen Kesehatan jumlah remaja pengonsumsi miras di Indonesia masih diangka 4,9\%, tetapi pada 2014 berdasarkan hasil riset yang dilakukan Gerakan Nasional Anti Miras 
(GeNAM) jumlahnya melonjak drastis hingga menyentuh angka 23\% dari total jumlah remaja Indonesia yang saat ini berjumlah 63 juta jiwa atau sekitar 14,4 juta orang.

Kebiasaan mengkonsumsi minuman keras pada masyarakat ini juga terjadi di Desa Sungai Jernih Kecamatan Seberang Musi Kabupaten Kepahiang. Mengkonsumsi minuman keras sering dilakukan oleh masyarakat desa tersebut, kebiasaan mengkonsumsi minuman keras pada masyarakat ini sering terjadi ketika ada hajatan pernikahan, sunatan, syukuran atau event kegiatan lainnya yang mengadakan suatu pertunjukan musik organ tunggal sebagai hiburan bagi masyarakat. Biasanya pertunjukan musik organ tunggal ketika ada hajatan ini oleh masyarakat sekitar di Desa Sungai Jernih disebut dengan acara Enjoy.

Acara enjoy atau pertunjukan musik organ tunggal pada malam hari ini biasanya memang diadakan oleh tuan rumah yang mempunyai hajatan, pertunjukan ini merupakan hiburan yang dominan ditampilkan pada saat hajatan perkawinan. Karena bagi masyarakat, terutama para remaja jika tidak menampilkan hiburan organ tunggal maka acara hajatan tersebut akan terasa ada yang kurang. Sebenarnya mengkonsumsi minuman keras merupakan suatu penyimpangan, karena kebiasaan mengkonsumsi minuman keras adalah tindakan tidak sesuai dengan norma, etika, agama, peraturan sekolah, keluarga dan lain-lain yang ada di dalam masyarakat.

Tetapi di Desa Sungai Jernih kebiasaan mengkonsumsi minuman keras pada masyarakat sekitar merupakan hal yang sudah biasa dilakukan, apalagi kebiasaan ketika adanya acara enjoy. Tidak ada larangan yang dilakukan oleh masyarakat, bahkan terkesan membiarkan masyarakat untuk mengkonsumsi minuman keras, sehingga berdasarkan uraian diatas acara enjoy telah menjadi sebuah tradisi dalam masyarakat Desa Sungai Jernih terutama remaja.

Fokus masalah dalam penelitian ini adalah mendeskripsikan tentang acara enjoy pada saat hajatan pernikahan sama halnya dengan acara mengkonsumsi minuman keras yang dibiarkan oleh masyarakat dan telah menjadi tradisi ketika ada hajatan pernikahan. Tujuan dari penelitian ini adalah untuk melihat mengapa meminum minuman keras dalam pesta hajatan pernikahan yang dalam istilah lokal disebut sebagai enjoy menjadi tradisi dalam masyarakat Desa Sungai Jernih. Teori yang digunakan adalah Social Bond Theory oleh Hirschi. Teori ini dilatarbelakangi oleh adanya teori 
kontrol sosial. Ide utama teori kontrol sosial adalah bahwa penyimpangan merupakan hasil dari kekosongan kontrol atau pengendalian sosial.

\section{METODE PENELITIAN}

Penelitian ini menggunakan metode penelitian kualitatif dan dilakukan di desa Sungai Jernih, Kecamatan Seberang Musi, Kabupaten Kepahiang. Alasan dipilihnya lokasi penelitan ini didasarkan pada masyarakat di desa Sungai Jernih masih sering adanya tradisi acara enjoy pada masyarakat dan kebiasaan mengkonsumsi minuman keras pada saat acara enjoy. Metode pengumpulan data yang digunakan dalam penelitian ini yakni dengan menggunakan metode observasi, wawancara, dan dokumentasi. Penentuan informan dalam penelitian ini dilakukan dengan menggunakan teknik Snowball Sampling. Teknik analisis data yang digunakan yakni reduksi data, penyajian data, serta penarikan kesimpulan.

\section{PEMBAHASAN}

\section{Keramaian Hajatan Pernikahan Di Wilayah Desa Sungai Jernih}

\section{Penyelenggaraan Hajatan}

Hajatan-hajatan yang biasanya melibatkan orang banyak dalam masyarakat Desa Sungai Jernih adalah hajatan-hajatan seperti pernikahan, masyarakat disekitar desa tersebut akan membantu hajatan tersebut secara gotong royong, dari awal akan diadakannya hajatan tersebut sampai hajatan tersebut selesai masyarakat Desa Sungai Jernih akan membantu, dan biasanya yang ditunggu-tunggu oleh masyarakat sekitar dalam hajatan tersebut adalah acara hiburannya yaitu pertunjukan musik organ tunggal.

\section{Perkembangan Hiburan Musik Organ Tunggal}

Hiburan musik organ tunggal di Desa Sungai Jernih mulai diminati oleh masyarakat pada awalan tahun 2000. Sebelum adanya organ tunggal biasanya hajatanhajatan hanya menampilkan kesenian-kesenian tradisional yang sederhana, seperti taritarian dan nyanyian yang dilakukan para ibu-ibu (Robana). Setelah masyarakat sudah banyak tinggal di desa tersebut dan masyarakatnya sudah mulai ramai barulah sering dilakukannya hajatan di Desa Sungai Jernih. Mulai saat itulah hiburan musik organ 
tunggal mulai sering diadakan di Desa Sungai Jernih, yang lambat laun menjadi hiburan wajib saat diadakannya hajatan.

\section{Pertunjukan Musik OrganTunggal Dalam Hajatan}

a. Pertunjukan Organ Tunggal Pada Siang Hari

Pertunjukan musik organ tunggal yang dimainkan pada siang hari biasanya dilakukan untuk menghibur para tamu undangan yang datang ketika hajatan berlangsung. Tamu-tamu undangan yang data pada siang hari ini kebanyakan adalah orang tua atau bapak-bapak dan ibu-ibu, serta pihak besan dari pengantin jika itu hajatan pernikahan, selain menghibur para tamu undangan, diadakannya hiburan musik organ tunggal ini juga untuk menghibur masyarakat desa yang telah membantu hajatan tersebut sebelumnya.

\section{b. Pertunjukan Organ Tunggal Pada Malam Hari}

Acara hiburan organ tunggal pada malam hari adalah acara yang ditujukan untuk para muda-mudi, baik itu muda-mudi desa yang mempunyai hajatan atau mudamudi desa lain. Acara musik organ tunggal pada malam hari ini susunan acara inti atau acara resminya hampir sama dengan acara pada siang hari, yang membedakannya hanya tamu undangan yang semuanya muda-mudi sedangkan pada siang hari kebanyakan orang tua dan suasana setelah acara inti selesai yang lebih sedikit bebas dan tanpa aturan.

\section{Musik Organ Tunggal Sebagai Hiburan Masyarakat}

Musik organ tunggal telah menjadi hiburan yang sangat menarik dalam masyarakat sekarang itu, terutama dalam masyarakat yang akan melakukan hajatan, Musik organ tunggal sebagai hiburan masyarakat disukai oleh berbagai kalangan mulai dari anak-anak hingga sampai orang tua, karena musik organ tunggal dapat mengiringi semua jenis musik dan lagu. Dengan adanya musik organ tunggal sebagai hiburan masyarakat dalam setiap ada hajatan di Desa Sungai Jernih, juga menimbulkan tradisi baru didalam masyarakat desa tersebut, terutama saat acara hiburan musik organ tunggal pada malam hari dikalangan pemuda-pemuda desa dan bapak-bapak. Dimana saat acara hiburan organ tunggal malam hari ini ada kebiasaan para pemuda-pemuda dan bapak-bapak untuk mengkonsumsi minuman keras dan mabuk-mabukan dengan bebas, bahkan dibiarkan, kebiasaan ini oleh masyarakat lokal disebut dengan acara enjoy. 


\section{Acara Enjoy Dalam Hajatan Pernikahan}

\section{Sejarah Adanya Acara Enjoy Saat Hajatan}

Pada tahun 2000, ketika musik organ tunggal baru mulai sering dimainkan di Desa Sungai Jernih, hanya ada hiburan musik organ tunggal pada siang hari untuk para tamu undangan dan dan jika ada acara hiburan musik organ tunggal pada malam hari hanya sebagai acara keluarga saja serta untuk hiburan untuk masyarakat yang telah membantu hajatan tersebut. Beberapa tahun kemudian sekitar tahun 2002, hiburan musik organ tunggal tidak ada hanya untuk kalangan keluarga tuan rumah hajatan dan bapak-bapak di pendapuran, karena banyaknya remaja desa-desa sekitar yang datang dan tamu-tamu undangan yang masih muda maka diadakanlah acara muda-mudi sebagai acara untuk mereka.

Setelah adanya acara muda-mudi barulah sekitar tahun 2005 atau 2006 mulai adanya acara mabuk-mabukan dengan diiringi musik organ tunggal yang disebut sebagai acara enjoy. Awalnya kebiasaan mabuk-mabukan ini disebut dengan acara batin budak karena yang ikut dalam acara tersebut adalah kalangan bapak-bapak muda (batin budak) tapi setelah acara ini sering diadakan setiap kali ada hajatan sebagai acara hiburan di malam hari, tidak hanya kalangan bapak-bapak muda (batin budak) saja yang menikmati acara tersebut, tetapi kalangan pemuda pun mulai mengikuti acara tersebut, dengan pemuda ikut dalam acara tersebut lama kelamaan acara tersebut disebut dengan acara enjoy.

\section{Perkembangan Acara Enjoy Saat Hajatan}

Pada perkembangannya acara enjoy yang awalnya hanya sebagai acara tambahan saat hiburan organ tunggal malam hari, sehingga acara enjoy ini tidak selalu ada di setiap kali hajatan. Acara enjoy ini ada jika ada permintaan dari para kalangan bapak-bapak muda (batin budak) dan pemuda-pemuda desa untuk diadakanya acara enjoy. Seiring perkembangannya acara enjoy sekarang ini tidak lagi menjadi acara tambahan pada saat ada hajatan untuk memperpanjang waktu, melainkan telah menjadi acara wajib ada pada saat hajatan. Jika sebelumnya untuk mengadakan acara enjoy harus meminta izin terlebih dahulu dari tuan rumah yang mempunyai hajatan agar acara tersebut boleh diadakan dan harus ada kesanggupan dari panitia hajatan untuk mengadakan acara enjoy. Tetapi untuk sekarang ini, meski tidak meminta persetujuan 
dari pihak tuan rumah hajatan acara enjoy masih akan tetap diadakan saat hajatan tersebut sebagai hiburan pada malam hari.

\section{Pengendalian Sosial Terhadap Acara Enjoy}

Acara enjoy sebagai tradisi meminum-minuman keras ketika pesta hajatan perkawinan dalam masyarakat Desa Sungai Jernih terjadi karena mengkonsumsi minuman keras dalam acara tersebut tidak mendapatkan larangan dari aparat keamanan, perangkat desa, dan masyarakat desa. Kebiasaan mengkonsumsi minuman keras dan mabuk-mabukan ketika pesta hajatan perkawinan yang disebut dengan acara enjoy tidak mendapatkan larangan dari aparat kepolisian karena selama acara tersebut ada di Desa Sungai Jernih dan di desa sekitar belum pernah terjadi tindakan kriminalitas seperti pembunuhan, perkelahian atau pencurian, selama adanya acara enjoy tersebut. Tidak adanya larang ini juga terjadi karena biasanya aparat kepolisian yang di undang atau yang datang pada acara tersebut adalah aparat kepolisian yang berasal dari daerah yang sama atau satu suku dari Pasemah dan biasanya perangkat desa sudah kenal dengan polisi dan sudah biasa di undang ketika ada acara enjoy untuk mengamankan.

\section{Alasan Adanya Kebiasaan Meminum-minuman Keras Pada Acara Enjoy}

Mengkonsumsi minuman keras yang dilakukan oleh masyarakat Desa Sungai Jernih terutama oleh kalangan bapak-bapak muda (batin budak) dan kalangan pemuda, telah menjadi kebiasaan bahkan telah mentradisi dalam masyarakat Desa Sungai Jernih terjadi dengan beberapa alasan, antara lain alasan masyarakat Desa Sungai Jernih ketika ada pesta hajatan pernikahan mengadakan acara enjoy dan memilih minuman keras sebagai hiburannya adalah karena wilayah Desa Sungai Jernih bisa dikatakan dalam kawasan yang marginal dan masyarakat Desa Sungai Jernih butuh hiburan dari tekanan atau stres dari lingkungan sekitar, sehingga untuk melepas kepenatan dan tekanan lingkungan tempat tinggal tersebut yang dilakukan oleh masyarakat Desa Sungai Jernih terutama oleh kalangan batin budak dan pemuda adalah dengan meminum-minuman keras ketika ada pesta hajatan pernikahan di desa tersebut. Adanya kebiasaan masyarakat Desa Sungai Jernih mengkonsumsi minuman keras pada saat pesta hajatan perkawinan, yang mereka sebut dengan acara enjoy juga terjadi karena Desa Sungai Jernih berada tidak jauh dari daerah Pasemah Air Keruh. Hal ini karena Daerah Pasemah Air Keruh sendiri terkenal dengan daerah yang cukup bebas dan tingkat kriminalitas yang tinggi dan peredaran minuman keras yang bebas. 


\section{Fungsi Adanya Acara Enjoy}

1. Enjoy Sebagai Acara Hiburan Bagi Masyarakat

Acara enjoy selain telah menjadi hiburan bagi masyarakat Desa Sungai Jernih, juga menjadi hiburan yang selalu mengiringi setiap kali hajatan, jika bagi kalangan masyarakat biasa (ibu-ibu, gadis, keluarga tuan rumah hajatan) yang menjadi hiburan mereka adalah melihat para biduan-biduan beraksidi atas panggung dan melihat para pemuda berjoget dengan biduan, berbeda dengan kalangan bapak-bapak muda (batin budak) dan kalangan pemuda, yang menjadi hiburan mereka pada acara enjoy adalah ketika mereka bisa joget bersama biduan dan bisa mengkonsumsi minuman keras dengan bebas dan mabuk-mabukan.

\section{Acara Enjoy Untuk Memeriahkan Hajatan}

Acara enjoy tidak hanya memeriahkan hajatan tersebut saat malam hari ketika acara enjoy berlangsung, dengan adanya acara enjoy juga memberi dampak pada meriah atau tidaknya hajatan tersebut pada hari sebelum-sebelumnya. Karena dengan adanya acara enjoy bukan hanya sebagai hiburan untuk masyarakat saja melainkan dengan adanya acara enjoy juga mengajak masyarakat sekitar Desa Sungai Jernih untuk meramaikan hajatan tersebut dari awal sampai hajatan tersebut selesai.

\section{Acara Enjoy Sebagai Prestise Dalam Masyarakat}

Ketika suatu hajatan tersebut pada malam harinya menyajikan hiburan musik organ tunggal dan adaacara enjoynya maka tuan rumah hajatan akan banyak mendapatkan omongan-omongan baik dari masyarakat sekitar seperti tuan rumah hajatan tersebut mengerti hiburan masyarakat, orang yang tidak sayang uang, dan omongan-omongan lainnya, sebaliknya jika hajatan tersebut tidak ada acara enjoynya, mereka akan banyak mendapatkan omongan-omongan yang tidak enak dari masyarakat, dikatakan hajatan tidak menghibur, pelit, tidak punya uang, dan lainlainnya, sehingga membuat tuan rumah hajatan mau tidak mau untuk menyajikan acara enjoy tersebut pada malam hari, karena tidak mau mendengarkan omongan-omongan yang tidak enak tersebut.

\section{Respon Masyarakat Terhadap Adanya Acara Enjoy}

Respon masyarakat akan acara enjoy sebagaian besar tidak begitu mempermasalahkan adanya acara tersebut dan membiarkan saja kebiasaan masyarakat mengkonsumsi minuman keras pada saat acara enjoy, sebagian besar masyarakat sudah 
tidak peduli akan kebiasaan masyarakat mengkonsumsi minuman keras pada saat acara enjoy.

\section{Analisis Tradisi Acara Enjoy Dengan Teori Kontrol Sosial}

Kebiasaan mengkonsusmsi minuman keras saat acara enjoy pada masyarakat Desa Sungai Jernih yang telah menjadi tradisi ketika ada hajatan ini bisa saja terjadi karena kontrol sosial dalam masyarakat tidak terjalin dengan baik, sehingga kebiasaankebiasaan yang tidak baik tersebut, seperti mengkonsumsi minuman keras yang dibiarkan, lama-kelamaan menjadi menjadi kebiasaan dan menjadi tradisi dalam masyarakat. Kebiasaan mengkonsumsi minuman keras pada saat acara enjoy yang telah menjadi tradisi ini juga disebabkan karena kegagalan yang dilakukan oleh lingkungan sekitar. Lemahnya kontrol sosial pada masyarakat Desa Sungai Jernih terlihat dari berbagai aktivitas atau kegiatan dari tokoh-tokoh masyarakat di Desa Sungai Jernih seperti tokoh agama, tokoh adat, perangkat desa dan aparat kemanan, yang mempunyai peran untuk mengkontrol masyarakat sekitar dari berbagai aspek kehidupan.

Kontrol sosial dari masyarakat dalam teori kontrol ada empat unsur utama yang mengontrol semua tindakan yang dianggap tidak sesuai dengan nilai dan norma, dengan kontrol kempat unsur-unsur tersebut tindakan-tindakan yang tidak sesuai tersebut dapat diminimalisir. Keempat unsur itulah yang dianggap sebagai Social Bond Theory yang berfungsi untuk mengendalikan perilaku dalam masyarakat. Dalam teori ini, beranggapan bahwa kegiatan-kegiatan yang menyimpang dalam masyarakat dapat diminimalkan ketika orang-orang tersebut memiliki keempat ikatan-ikatan tersebut, yaitu berupa kasih sayang, tanggung jawab, keterlibatan, dan kepercayaan.

\section{KESIMPULAN}

Acara enjoy telah menjadi tradisi baru dalam masyarakat Desa Sungai Jernih sejak tahun 2005 sampai sekarang ini, menjadinya acara enjoy ini sebagai tradisi baru ketika ada masyarakat yang melakukan pesta hajatan pernikahan terjadi karena adanya beberapa alasan yaitu tidak adanya larangan dari aparat keamanan yang ada di sekitar desa tersebut. Dengan adanya acara enjoy ketika ada masyarakat melakukan hajatan menjadi hiburan bagi masyarakat, mereka beramai-ramai menyaksikan acara tersebut sampai larut malam. 
Acara enjoy sendiri tidak terlepas dari kebiasaan masyarakat mengkonsumsi minuman keras. Kebiasaan mengkonsumsi minuman keras ketika ada acara enjoy karena pada saat ada acara tersebut masyarakat yang mengkonsumsi minuman keras tidak mendapatkan larangan dari masyarakat sekitar dan pihak aparat keamanan yang datang, bahkan pada acara tersebut konsumsi minuman keras dan mabuk-mabukan dibiarkan oleh aparat kemanan, selain tidak adanya larangan mengkonsumsi minuman keras, pada saat acara enjoy minuman keras diperjual belikan bebas.

Saran yang diberikan berdasarkan hasil penelitian yaitu (1) saran jangka pendek, kepada pemeritah Kabupaten Kepahiang atau Kecamatan Seberang Musi untuk memberikan peraturan tentang acara enjoy tersebut, dimana dalam acara tersebut ada kebiasaan masyarakat mengkonsumsi minuman keras dan dengan bebas melakukannya (2) saran jangka panjang, dari peneliti untuk menghilangkan kebiasaan atau tradisi tersebut dalam masyarakat Desa Sungai Jernih, maka diperlukan juga penanaman nilainilai baru yang sesuai dengan nilai dan norma yang berlaku dalam masyarakat atau nilai dan norma yang baik. Dalam penanaman nilai-nilai yang baru tersebut agar tercapai dan diterapkan dengan baik oleh masyarakat Desa Sungai Jernih maka diperlukan proses pelembagaan yang melibatkan seluruh lembaga di desa tersebut, sehingga nilai-nilai baru tersebut dengan mudah masuh dan tertanam dalam masyarakat.

\section{DAFTAR PUSTAKA}

Ahmed. 2010. Ciu Minuman Khas Solo Antara Simbol Perlawanan dan Simbol Setan. 11Mei, 2017 (Ahmadfikreatif.blogspot.co.id).

Cahyo, Nur. 2015. Kenakalan Remaja dan Pariwisata Dalam Tinjauan Teori Kontrol Sosial Travis Hirschi. Surabaya: UIN Sunan Ampel Surabaya. 3 Desember, 2016 (digilib.uinsby.ac.id).

Hukum Online. 2015. Ketentuan Mengenai Penjualan dan Promosi Minuman Beralkohol. 2 November, 2016 (www.hukumonline.com).

Koentjaraningrat. 2005. Pengantar Antropologi. Jakarta: Rineka Cipta.

Narwoko, Dwi dan Bagong, Suyanto.2004. Sosiologi Teks Pengantar dan Terapan. Jakarta: Kencana.

Santrock, W. Jhon. 2007. Remaja. Jakarta: Erlangga. 
Septariani, Retno. 2016. "Perkelahian Antar Remaja Ketika Hiburan Organ Tunggal di Saat Pesta Pernikahan". Skripsi. Bengkulu: Universitas Bengkulu.

Soekanto, Soerjono. 2004. Sosiologi Keluarga. Jakarta: Rineka Cipta.

Syarbaini, Syahrial. 2009. Dasar-dasar Sosiologi. Jakarta: Graha Ilmu. 